\title{
Post-Tuberculosis (TB) Treatment: The Role of Surgery and Rehabilitation
}

\author{
Dina Visca ${ }^{1,2,+}{ }^{\text {, Simon Tiberi }}{ }^{3,4,+}{ }^{+}$, Rosella Centis ${ }^{5}$, Lia D'Ambrosio ${ }^{6}{ }^{\oplus}$, Emanuele Pontali ${ }^{7}$, \\ Alessandro Wasum Mariani ${ }^{8,9}{ }^{\circ}$, Elisabetta Zampogna ${ }^{1}{ }^{10}$, Martin van den Boom ${ }^{10}$, \\ Antonio Spanevello ${ }^{1,2}$ and Giovanni Battista Migliori ${ }^{5, *}$ \\ 1 Division of Pulmonary Rehabilitation, Istituti Clinici Scientifici Maugeri IRCCS, 21049 Tradate, Italy; \\ dina.visca@icsmaugeri.it (D.V.); elisabetta.zampogna@icsmaugeri.it (E.Z.); \\ antonio.spanevello@icsmaugeri.it (A.S.) \\ Department of Medicine and Surgery, Respiratory Diseases, University of Insubria, 21100 Varese, Italy \\ 3 Blizard Institute, Barts and The London School of Medicine and Dentistry, Queen Mary University of \\ London, London E1 4NS, UK; simon.tiberi@nhs.net \\ 4 Division of Infection, Royal London Hospital, Barts Health NHS Trust, London E1 1BB, UK \\ 5 Servizio di Epidemiologia Clinica delle Malattie Respiratorie, Istituti Clinici Scientifici Maugeri IRCCS, \\ 21049 Tradate, Italy; rosella.centis@icsmaugeri.it \\ 6 Public Health Consulting Group, 6900 Lugano, Switzerland; lia.dambrosio59@gmail.com \\ 7 Department of Infectious Diseases, Galliera Hospital, 16128 Genova, Italy; pontals@yahoo.com \\ 8 Departamento de Cirurgia Toracica, Instituto do Coracao, Hospital das Clinicas HC-FMUSP, \\ Sao Paulo 05403-000, Brazil; awmariani@gmail.com \\ 9 Disciplina de Cirurgia Torácica, Faculdade de Medicina, Universidade de São Paulo, \\ São Paulo 05508-220, Brazil \\ 10 Joint TB, HIV and Viral Hepatitis Programme, Division of Health Emergencies and Communicable Diseases, \\ WHO Regional Office for Europe, 2100 Copenhagen, Denmark; vandenboomm@who.int \\ * Correspondence: giovannibattista.migliori@icsmaugeri.it \\ + equally contributed.
}

Received: 3 March 2020; Accepted: 10 April 2020; Published: 15 April 2020

\begin{abstract}
Even though the majority of tuberculosis (TB) programmes consider their work completed when a patient is 'successfully' cured, patients often continue to suffer with post-treatment or surgical sequelae. This review focuses on describing the available evidence with regard to the diagnosis and management of post-treatment and surgical sequelae (pulmonary rehabilitation). We carried out a non-systematic literature review based on a PubMed search using specific key-words, including various combinations of 'TB', 'MDR-TB', 'XDR-TB', 'surgery', 'functional evaluation', 'sequelae' and 'pulmonary rehabilitation'. References of the most important papers were retrieved to improve the search accuracy. We identified the main areas of interest to describe the topic as follows: 1) 'Surgery', described through observational studies and reviews, systematic reviews and meta-analyses, IPD (individual data meta-analyses), and official guidelines (GRADE (Grading of Recommendations Assessment, Development and Evaluation) or not GRADE-based); 2) Post-TB treatment functional evaluation; and 3) Pulmonary rehabilitation interventions. We also highlighted the priority areas for research for the three main areas of interest. The collection of high-quality standardized variables would allow advances in the understanding of the need for, and effectiveness of, pulmonary rehabilitation at both the individual and the programmatic level. The initial evidence supports the importance of the adequate functional evaluation of these patients, which is necessary to identify those who will benefit from pulmonary rehabilitation.
\end{abstract}

Keywords: TB; post-treatment sequelae; surgery; pulmonary rehabilitation 


\section{Introduction}

Pulmonary and pleural tuberculosis (TB) may be severe and challenging even with drug susceptible strains of Mycobacterium tuberculosis and may require a multidisciplinary approach for best management. Moreover, drug-resistant tuberculosis (TB) and, in particular, multidrug-resistant (MDR) and extensively drug-resistant (XDR) TB frequently occur in patients who have had prior TB episodes and may worsen previously damaged lungs [1-3]. Managing these cases is difficult, requiring a multidisciplinary team approach [4] and expensive treatment (which is toxic and with treatment success still below expectations) $[2,5]$.

The availability of new drugs (bedaquiline, delamanid, and pretomanid) after many years of neglect provides new perspectives, improved success rates and a reduced prevalence of adverse events [6-8]. The rapid detection of TB is also key in order to catch the disease process early and preserve lung function.

As new evidence is made available and more is known about drugs and regimens, more patients are surviving [9-12], and it is emerging that other aspects require attention: the importance of preventing transmission [13], ensuring adequate nutrition, considering adjuvant surgery, and post-treatment sequelae $[2,3,14]$. These were emphasised in a comprehensive review of the Global Tuberculosis Network (GTN) based on the consensus of about 100 global experts [2]. This review is focused on describing the available evidence on adjuvant surgery and diagnosis and management of post-treatment sequelae (pulmonary rehabilitation).

\section{Materials and Methods}

We carried out a non-systematic literature review based on a PubMed search using specific key-words, including various combinations of 'TB', 'MDR-TB', 'XDR-TB', 'surgery', 'functional evaluation', 'sequelae', and 'pulmonary rehabilitation'. References of the existing reviews were retrieved to improve accuracy.

Manuscripts written in English, Spanish, and Russian were selected, including full articles and relevant abstracts.

The main areas of interest we identified to describe the topic are as follows:

1) 'Surgery', described through observational studies and reviews, systematic reviews, and meta-analyses, IPD (individual data meta-analyses) and official guidelines (GRADE or not GRADE-based). Due to the scant evidence on thoracoplasty and other less frequent surgical procedures, we concentrated on lung resection.

2) Post-TB treatment lung functional evaluations.

3) Pulmonary rehabilitation interventions.

The priorities for research have been identified for each main area of interest.

\section{Surgery and TB}

\subsection{Observational Studies and Reviews}

A limited number of observational studies and reviews are available on the topic; the majority suggests that adjuvant surgery in selected patients may be useful to improve treatment outcomes [2,15-27]. However, the strength of the conclusions from these studies is somewhat limited by the risk of bias related to the variability of the centres' procedures, patients' profiles, treatment regimens, timing and types of surgical procedures, and it is difficult, if not impossible, to identify homogenous patients to compare among studies. 


\subsection{Traditional Meta-analyses}

A few meta-analyses are available on the topic [28-32]. A traditional meta-analysis of 15 reports of surgical resection found that treatment success was achieved in $84 \%$ (95\% confidence interval (CI), $78 \%-89 \%$ ) of patients, noting substantial heterogeneity among the studies [29].

Two other meta-analyses of MDR-TB patients who had either resection or non-resection surgery found that surgical patients had better outcomes than those who did not [28,30]; however, there was no distinction between the different forms of resection surgery.

In the Marrone's meta-analysis [28], 24 studies identified a significant association between surgery and successful treatment compared to non-surgical interventions (OR 2.24, 95\%CI 1.68-2.97). The meta-analysis from 23 single-arm studies demonstrated that, respectively, 92\% (95\%CI 88.1-95) and $87 \%$ (95\% CI 83-91) of surgical patients achieved successful short and long-term outcomes. In the sub-group analysis (studies reporting both surgical and non-surgical treatment outcomes) favourable surgical outcomes (treatment success) were associated with increased drug-resistance, i.e., better results for XDR-TB patients than for MDR-TB ones.

Confounding by indication (a form of bias that occurs when the patients most likely to benefit are selected for therapy) was a major limitation in each meta-analysis.

Furthermore, antibiotic regimens were not standardized across studies, meaning that the studies could not account for factors such as the individual drug regimens or the timing of surgery in relation to culture conversion.

\subsection{Evaluating the Role of Surgery Through IPD}

A recent IPD based on the large MDR-TB cohort coordinated by McGill University [33-35] utilized a sophisticated analysis (propensity score matching) to evaluate the benefits offered by surgery. Individual patient data from 26 cohort studies were analysed, including clinical features and information on both medical and surgical therapy. Primary analyses compared treatment success (cure and completion) to a combined outcome of failure, relapse, or death. The effects of all forms of resection surgery, pneumonectomy, and partial lung resection were evaluated [35].

The final analysis was conducted on 4,238 patients from 18 surgical studies and 2,193 from 8 non-surgical ones. Pulmonary resection surgery (478 patients) was associated with improved treatment success (adjusted odds ratio (aOR), 3.0; 95\% confidence interval (CI), 1.5-5.9), but pneumonectomy was not (aOR, 1.1; 95\% CI, 0.6-2.3). Treatment success was achieved in $95.2 \%$ of patients undergoing surgery after culture conversion compared with $91.2 \%$ of those who had surgery before it $(\mathrm{aOR}, 2.6$; 95\% CI, 0.9-7.1).

Patients undergoing partial lung resection achieved better treatment success and lower failure/death rates than patients who had either pneumonectomy or no surgery. The median duration of medical therapy was 20 months (interquartile range [IQR], 13.7-24.0 months) for those who had surgery after culture conversion versus 29 months (IQR, 22-45 months) for those undergoing surgery before conversion. The loss to follow-up was lower among patients who had surgery $(11 \% ; 95 \% \mathrm{CI}$, $4-17 \%)$ than among those who had not (22\%; 95\% CI, $14-31 \%)$.

The authors concluded that, among MDR-TB patients, partial lung resection (but not pneumonectomy) was associated with improved treatment success, although selection bias cannot be excluded [35]. This finding can be explained with the lower rate of mortality among surgical versus non-surgical TB patients. Furthermore, patients undergoing surgery had, overall, more severe drug-resistance profiles and more extensive diseases [35]. Importantly, both surgical and non-surgical patients were rather young with a low probability of confounding co-morbidities [35].

A summary of the available evidence is reported in Table 1 
Table 1. Main reports on the indications, type, and outcomes of surgery performed in patients affected by pulmonary tuberculosis complications.

\begin{tabular}{|c|c|c|c|c|c|c|c|}
\hline $\begin{array}{l}\text { First Author, } \\
\text { Year, Country }\end{array}$ & Reference & $\begin{array}{l}\text { Type of Paper; } \\
\text { Patients Number and } \\
\text { MDR/XDR-TB } \\
\text { Proportion (\%) }\end{array}$ & $\begin{array}{l}\text { Indications for Surgery; } \\
\text { Type of Surgery Assessed }\end{array}$ & $\begin{array}{l}\text { Timing of } \\
\text { Surgery }\end{array}$ & $\begin{array}{l}\text { Favorable } \\
\text { Outcome } \\
\text { (Treatment } \\
\text { Success) }\end{array}$ & $\begin{array}{l}\text { Post-operative } \\
\text { Complications/ } \\
\text { Mortality (within } 30 \\
\text { Days from Surgery) } \\
\end{array}$ & $\begin{array}{c}\text { Favouring } \\
\text { Surgery }\end{array}$ \\
\hline $\begin{array}{c}\text { Sayir, } \\
\text { 2019, Turkey }\end{array}$ & [24] & $\begin{array}{c}\text { Case series; } \\
9 \text { pts, unspecified } \\
\text { MDR/XDR \% }\end{array}$ & $\begin{array}{l}\text { Emergency: hemorrhage } \\
\text { Elective: empyema } \\
\text { Unspecified type of surgery }\end{array}$ & $\begin{array}{l}\text { - After sputum } \\
\text { smear negativity } \\
\text { was achieved } \\
\text { - After negative } \\
\text { culture for } \\
\text { empyema }\end{array}$ & Unspecified & $\begin{array}{l}\text { Complications: } \\
\text { unspecified } \\
\text { Mortality: } 11.1 \%\end{array}$ & N/A \\
\hline $\begin{array}{l}\text { Yablonskii, } \\
\text { 2019, Russia }\end{array}$ & [25] & $\begin{array}{c}\text { Review; } \\
\text { N/A pts and } \\
\text { MDR/XDR \% }\end{array}$ & $\begin{array}{l}\text { Emergency: hemorrhage, } \\
\text { spontaneous pneumothorax } \\
\text { Urgent: recurrent haemoptysis } \\
\text { Elective: localized cavitary disease } \\
\text { with persistent sputum positivity } \\
\text { Complications of TB diseases } \\
\text { Assessment of all types of surgery }\end{array}$ & Unspecified & $\begin{array}{c}\text { Treatment success: } \\
\quad 67 \%-100 \%\end{array}$ & $\begin{array}{c}\text { Complications: } \\
\text { 9\%-30.8\% } \\
\text { Mortality: } 0-5.5 \%\end{array}$ & N/A \\
\hline $\begin{array}{c}\text { Borisov, } \\
\text { 2019, Several } \\
\text { Countries }\end{array}$ & [20] & $\begin{array}{c}\text { Case series; } \\
55 \text { pts, } 43.6 \% \text { at least } \\
\text { MDR; } 56.4 \% \text { XDR }\end{array}$ & $\begin{array}{l}\text { Localised disease allowing for } \\
\text { resection, failed bacteriological } \\
\text { conversion, disease worsening } \\
\text { Mostly lobectomy, segmentectomy, } \\
\text { pneumonectomy }\end{array}$ & $\begin{array}{l}\text { After } 8 \text { months of } \\
\text { therapy (median); } \\
\text { range: } 5-13)\end{array}$ & $\begin{array}{c}\text { Treatment success } \\
69.1 \%\end{array}$ & $\begin{array}{l}\text { Complications: } 23.7 \% \\
\text { (out of } 38 \text { evaluable } \\
\text { patients) } \\
\text { Mortality: } 0\end{array}$ & N/A \\
\hline $\begin{array}{l}\text { Chen, } \\
\text { 2018, China }\end{array}$ & [26] & $\begin{array}{c}\text { Case series; } \\
32 \text { pts, } 12.5 \% \text { MDR }\end{array}$ & $\begin{array}{c}\text { Haemoptysis }(100 \%) \text {, continuously } \\
\text { positive smear }(28.1 \%), \text { pulmonary } \\
\text { aspergillosis }(40.6 \%) \\
\text { Regional arterial embolization } \\
\text { followed by pulmonary resection } \\
\text { Fibro-cavitary and cavitary }\end{array}$ & $\begin{array}{c}\text { After at least } 6 \\
\text { months of } \\
\text { standard therapy }\end{array}$ & Unspecified & $\begin{array}{l}\text { Complications } 18.75 \% \\
\text { Mortality: unspecified }\end{array}$ & N/A \\
\hline $\begin{array}{l}\text { Giller, } \\
\text { 2018, Russia }\end{array}$ & [27] & $\begin{array}{c}\text { Case series; } \\
\text { 5,599 pts, unspecified } \\
\text { MDR/XDR \% }\end{array}$ & $\begin{array}{c}\text { pulmonary TB }(58.5 \%) \text {, tuberculoma } \\
\text { with destruction }(18.8 \%) \text {, tuberculous } \\
\text { pleural empyema }(18.8 \%) \text {, caseous } \\
\text { pneumonia }(3.4 \%), \text { intrathoracic } \\
\text { lymph nodes }(0.5 \%) \\
\text { Unspecified type of surgery }\end{array}$ & $\begin{array}{l}\text { After 1-3 years of } \\
\text { treatment (for } 84 \% \\
\text { of patients) }\end{array}$ & $\begin{array}{c}\text { Treatment success: } \\
92.1 \%-98 \%\end{array}$ & $\begin{array}{l}\text { Complications } 1.9 \% \\
\text { Mortality: } 0.1 \%\end{array}$ & N/A \\
\hline $\begin{array}{c}\text { Fox, } \\
2016, \text { N/A }\end{array}$ & [35] & $\begin{array}{c}\text { Meta-analysis; } \\
478 \text { pts (18 studies) } \\
\text { 100\% MDR (of whom } \\
\text { 8.6\% XDR) }\end{array}$ & $\begin{array}{c}\text { Unknown indication for surgery } \\
\text { Pneumonectomy (118 pts), partial } \\
\text { lung resection (227 pts), unspecified } \\
\text { (132 pts) }\end{array}$ & Unknown & $\begin{array}{l}\text { Treatment success* } \\
81 \% \\
\text { (pneumonectomy } \\
69 \% \text {; partial lung } \\
\text { resection } 90 \% \text { ) }\end{array}$ & $\begin{array}{l}\text { Complications: } \\
\text { unspecified } \\
\text { Mortality: } 8.4 \%(70 \% \\
\text { of deaths }>30 \text { days } \\
\text { from surgery) }\end{array}$ & Yes \\
\hline
\end{tabular}


Table 1. Cont.

\begin{tabular}{|c|c|c|c|c|c|c|c|}
\hline $\begin{array}{l}\text { First Author, } \\
\text { Year, Country }\end{array}$ & Reference & $\begin{array}{c}\text { Type of Paper; } \\
\text { Patients Number and } \\
\text { MDR/XDR-TB } \\
\text { Proportion (\%) }\end{array}$ & $\begin{array}{l}\text { Indications for Surgery; } \\
\text { Type of Surgery Assessed }\end{array}$ & $\begin{array}{l}\text { Timing of } \\
\text { Surgery }\end{array}$ & $\begin{array}{l}\text { Favorable } \\
\text { Outcome } \\
\text { (Treatment } \\
\text { Success) }\end{array}$ & $\begin{array}{c}\text { Post-operative } \\
\text { Complications/ } \\
\text { Mortality (within } 30 \\
\text { Days from Surgery) }\end{array}$ & $\begin{array}{l}\text { Favouring } \\
\text { Surgery }\end{array}$ \\
\hline $\begin{array}{l}\text { Subotic, } \\
\text { 2016, N/A }\end{array}$ & [23] & $\begin{array}{c}\text { Review; } \\
\text { N/A pts and } \\
\text { MDR/XDR \% }\end{array}$ & $\begin{array}{l}\text { Persistently positive sputum smear } \\
\text { and/or culture despite appropriate } \\
\text { chemotherapy, relapse, high risk of } \\
\text { relapse based on drug resistance } \\
\text { profile; } \\
\text { Lobectomy, pneumonectomy, } \\
\text { resection of tuberculoma }\end{array}$ & $\begin{array}{l}\text { For infectious TB } \\
\text { patients after at } \\
\text { least } 6-8 \text { months } \\
\text { of appropriate } \\
\text { anti-TB therapy }\end{array}$ & $\begin{array}{l}\text { Treatment success } \\
\text { after surgery } \\
\text { between } 75 \% \text { and } \\
98 \%\end{array}$ & $\begin{array}{c}\text { Complications: } \\
9 \%-26 \% \\
\text { Mortality: }<5 \% \text { after } \\
\text { lung resection for TB }\end{array}$ & N/A \\
\hline $\begin{array}{l}\text { Marrone, } \\
\text { 2013, N/A }\end{array}$ & [28] & $\begin{array}{l}\text { Systematic review and } \\
\text { meta-analysis; } \\
706 \text { pts, } 100 \% \\
\text { MDR/XDR }\end{array}$ & $\begin{array}{l}\text { Standardized or non-standardized } \\
\text { indication for surgery } \\
\text { Unspecified type of surgery }\end{array}$ & Unspecified & $\begin{array}{l}\text { Treatment success: } \\
87 \% \text { at twelve } \\
\text { months } \\
\text { post-surgery; more } \\
\text { favorable outcome } \\
\text { for XDR than for } \\
\text { MDR }\end{array}$ & $\begin{array}{l}\text { Complications: } 3 \% \\
\text { short-term; } 8 \% \\
\text { long-termMort } \\
\text { ality: unspecified }\end{array}$ & Yes \\
\hline $\begin{array}{c}\mathrm{Xu}, \\
2011, \mathrm{~N} / \mathrm{A}\end{array}$ & [29] & $\begin{array}{l}\text { Systematic review and } \\
\text { meta-analysis; } \\
949 \text { pts, } 100 \% \text { MDR }\end{array}$ & $\begin{array}{l}\text { Unspecified indication for surgery } \\
\text { Mainly pneumonectomy, lobectomy, } \\
\text { segmentectomy }\end{array}$ & Unspecified & $\begin{array}{l}\text { Treatment success: } \\
84 \%\end{array}$ & $\begin{array}{c}\text { Complications: } \\
\text { unspecified; Mortality: } \\
3 \%\end{array}$ & Unspecified \\
\hline
\end{tabular}

Legend: MDR: multidrug -resistant; XDR: extensively drug-resistant; ${ }^{*}$ excluding lost to follow up; TB: tuberculosis; N/A: not applicable, Pts: patients. 
3.4. World Health Organization (WHO), International Union Against Tuberculosis and Lung Disease (The UNION), and ATS/CDC/ERS/IDSA (American Thoracic Society/Centers for Disease Control and prevention/European Respiratory Society/Infectious Diseases Society of America) guidelines

In the consolidated WHO 2019 MDR-TB guidelines (and in the preceding 2016 and 2011 ones) the following recommendation were given (based on GRADE): in patients with rifampicin-resistant (RR)-TB or MDR-TB, elective partial lung resection (lobectomy or wedge resection) may be used alongside a recommended MDR-TB regimen [36].

In a regional WHO European guidance the indications and contra-indications for surgery were clearly defined $[19,37]$. Surgical interventions may have emergency (life threatening conditions), urgent (irreversible TB and haemoptysis), and elective natures.

Elective surgery indications include localised unilateral forms of bacteriologically-confirmed cavitary disease, MDR-/XDR-TB failing medical treatment, and complications/sequelae (spontaneous pneumothorax/pyopneumothorax; pleural empyema with or without bronchopleural fistula; aspergilloma; nodular-bronchial fistula; broncholith; and pachypleuritis/pericarditis with respiratory and blood circulation insufficiency; trachea/large bronchi stenosis; and post-TB bronchiectasis).

The following contra-indications have been identified [19,37]:

- $\quad$ Bilateral, extensive cavities;

- Impaired pulmonary function (forced expiratory volume in one second FEV1 (forced expiratory volume in $1 \mathrm{~s}$ ) <1.5 L for lobectomy and < 2.0 L for pneumonectomy);

- Pulmonary-heart failure III-IV (New York Hart Association functional classification);

- Body mass index (BMI) up to $40 \%-50 \%$ of normality;

- Severe co-morbid conditions (uncontrolled diabetes, ulcer exacerbation, and liver/renal insufficiency);

- $\quad$ Active bronchial TB.

The UNION guidelines (which are not designed with the GRADE approach) suggest that 'surgery should be considered for treating drug-resistant (DR)-TB only in patients meeting the three following conditions: 1) a fairly localised lesion, 2) an adequate respiratory reserve, and 3) a lack of sufficient available drugs to design a regimen potent enough to ensure a cure. Ideally, surgery needs to be performed at the moment chemotherapy has achieved the lowest possible bacillary load (sputum smear and culture converted to negative) within a complete cycle of chemotherapy [38].

In the recently published ATS/CDC/ERS/IDSA guidelines [39] the PICO (population, intervention, comparator, outcomes) question 19 was on 'Surgery for MDR-TB' as follows: 'Should elective lung resection surgery (i.e., a lobectomy or pneumonectomy) be used as an adjunctive therapeutic option in combination with antimicrobial therapy, versus medical therapy alone for adults with MDR-TB?'

The following recommendations were issued:

'Recommendation 19A: We suggest elective partial lung resection (e.g., a lobectomy or wedge resection), rather than medical therapy alone, for adults with MDR-TB receiving antimicrobial-based therapy (conditional recommendation, very low certainty in the evidence). The writing committee believes this option would be beneficial for patients for whom clinical judgement, supported by bacteriological and radiographic data, suggest a strong risk of treatment failure or relapse with medical therapy alone.

Recommendation 19B: We suggest medical therapy alone, rather than including elective total lung resection (pneumonectomy), for adults with MDR-TB receiving antimicrobial therapy (conditional recommendation, very low certainty of evidence)' [39].

In summary, all major guidelines are consistent in recommending surgery in selected cases, following chemotherapy and favouring elective partial lung resection when possible, based on specific indications: failure of drug therapy, relapse, localized (e.g., cavity) or extensive pulmonary TB, clinical complications (e.g., haemoptysis or empyema) [39]. However, recent evidence suggests that bilateral surgery can also be safe and effective [40]. 
The patients undergoing surgery are candidates for pulmonary rehabilitation [20,39].

\subsection{Priorities for Research}

The ATS/CDC/ERS/IDSA guidelines proposed the following priorities for TB research on TB and surgery [39]: ideal timing for surgery; optimal drug regimens and duration before and after surgery; the role of surgery in special populations and patients with co-morbidities (e.g., HIV co-infection), optimal surgical approaches, optimal infection control measures to be implemented peri-operatively, and the role of pulmonary rehabilitation.

\section{Post-TB Treatment Sequelae and Rehabilitation}

There is evidence that patients with pulmonary TB have up to a five to six times higher probability of abnormal pulmonary function when compared with LTBI (latent TB infection) individuals [41]. $\mathrm{TB}$ sequelae are likely to follow delayed diagnosis, extensive disease, and long and/or repeated treatments [42]. TB sequelae are risk factors for bronchiectasis and COPD (chronic obstructive pulmonary disease), both conditions are more common in smokers and in the presence of in-door or out-door drug pollution [43]. The most common alterations are represented by obstructions with or without restriction. Airflow obstruction is usually without response to the bronchodilator, and often coupled with bronchiectasis and/or tracheobronchial stenosis, alterations of the lung parenchyma (cavities and pulmonary fibrosis) or of the pleura (empyema, fibrothorax, bronchopleural fistula, and pneumothorax). Restriction can affect gas exchange, as well as other vascular complications including pulmonary or bronchial arteritis, thrombosis, artery dilatation, Rasmussen aneurysm, or 'cor pulmonale' [43]. Both mechanical and gas exchange alterations can limit daily activities, exercise capacity, and impair quality of life (QoL) [43].

\subsection{Post-TB Treatment Functional Evaluation}

A baseline examination with functional evaluation can be performed safely when the patient is smear and culture negative (on at least two samples two weeks apart) and is undergoing effective treatment; otherwise, infection control measures are necessary [13]. As the patient might need a different approach when resting and when making exercise (e.g., walking), a careful evaluation should be ideally performed both at rest and under exercise conditions $[43,44]$.

At rest, spirometry with response to the bronchodilator, diffusing capacity of the lung for carbon monoxide (DLCO), arterial blood gases analysis are recommended to study lung mechanics, complemented by plethysmography at the initial evaluation (if feasible) (Figure 1) [43].

Spirometry is the most widely accepted test to assess lung function impairment. It can be conducted with a simple spirometer, which costs a minimum of $150 \$$ and can be used at point-of-care or with a sophisticated apparatus which includes plethysmography (which is able to diagnose lung restriction and 'air trapping' by measuring the Residual Volume (RV)). The core parameters evaluated by spirometry are forced expiratory volume (FEV) ${ }_{1}$ (low $\mathrm{FEV}_{1}$ indicates airflow obstruction), FVC (Forced Vital Capacity) and their ratio $\left(\mathrm{FEV}_{1} / \mathrm{FVC}\right)$ [43]. DLCO describes the status of gas exchanges at the pulmonary level, which can be hampered even in the presence of normal spirometry and plethysmography.

Under exercise conditions it is useful to have the patient undergo the 6-min walking test (6MWT) or the cardiopulmonary exercise test (CPET) which provides additional information on the physiological reserve (and, indirectly on QoL) $[43,44]$. The $6 M W T$ measures the distance covered (in metres) in $6 \mathrm{~min}$. It can be done in any setting, is cheap and easy to interpret: it correlates with QoL and improves after rehabilitation [43-45]. CPET is a more sophisticated, expensive, and technology-dependent tool which cannot be performed in all centres. It provides information on the exercise capacity-limiting determinants (respiratory: mechanical or as exchange-related; muscular; and cardio-vascular). 


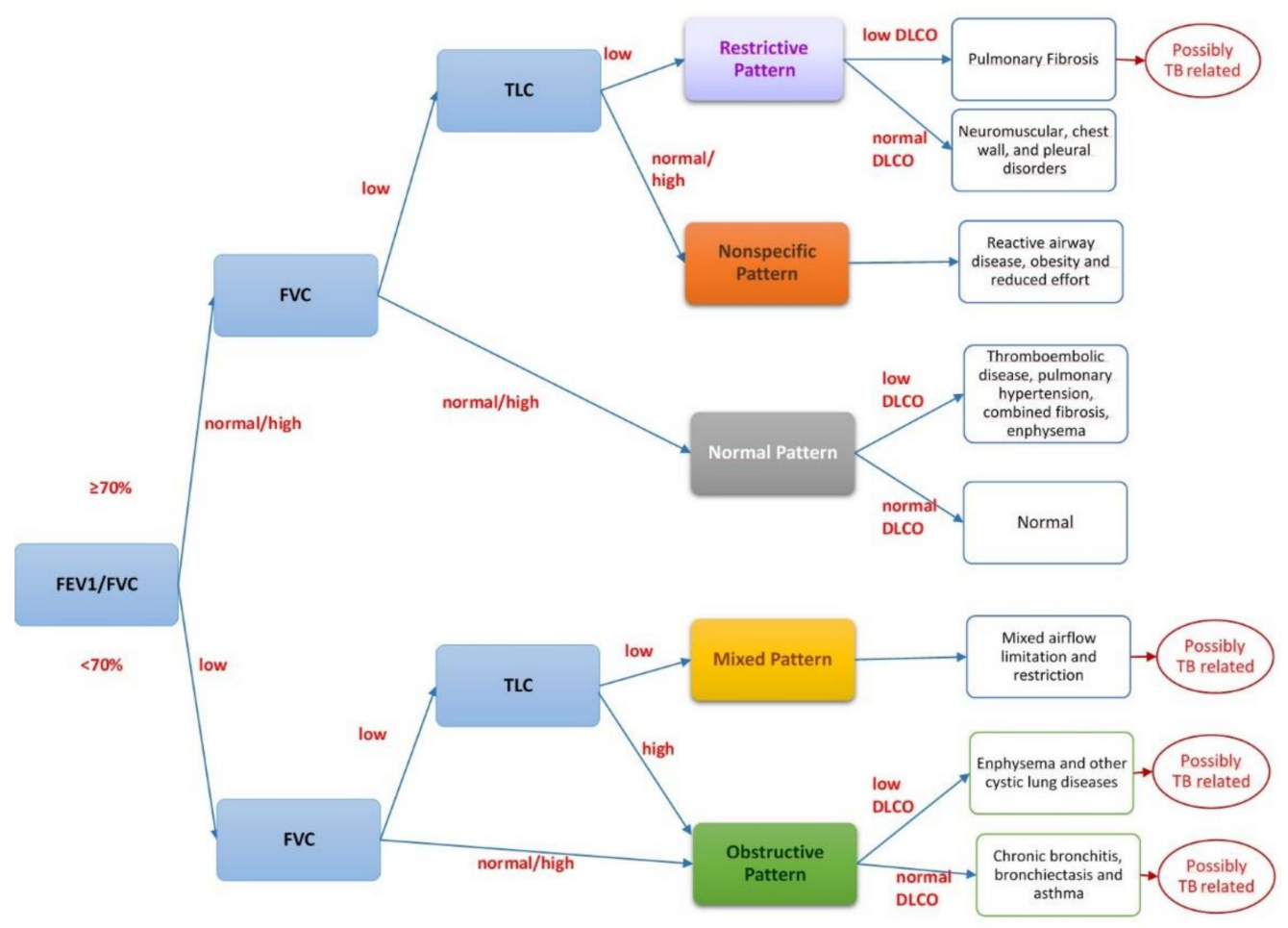

Figure 1. Interpreting spirometry. Legend: FEV1: forced expiratory volume in $1 \mathrm{~s}$; FVC: forced vital capacity; FEV1/FVC ratio: the percentage of the FVC expired in one second; DLCO: diffusing capacity of the lung for carbon monoxide; TLC: total lung capacity.

Different tools exist to evaluate QoL, including generic questionnaires (e.g., 36-item Short Form (SF) health survey or SF-36 and its shortened version with 12 questions, the SF-12) or specific tools as the SGRQ (St. Georges's Respiratory Questionnaire) specifically investigating QoL in chronic respiratory diseases (Table 2). 
Table 2. Available tests to evaluate health-related quality of life (HRQoL).

\begin{tabular}{|c|c|c|c|}
\hline \multicolumn{4}{|c|}{ NON-DISEASE SPECIFIC } \\
\hline $\begin{array}{l}\text { Questionnaire } \\
\text { and Items }\end{array}$ & Domains & $\begin{array}{l}\text { Mode and Time of } \\
\text { Administration }\end{array}$ & Score \\
\hline $\begin{array}{c}\text { The Short Form (36) Health } \\
\text { Survey } \\
\text { SF-36v2 } \\
36 \text { items }\end{array}$ & $\begin{array}{ll}\text { 1. } & \text { Vitality } \\
\text { 2. } & \text { Physical functioning } \\
\text { 3. } & \text { Bodily pain } \\
\text { 4. } & \text { General health perceptions } \\
\text { 5. } & \text { Physical role functioning } \\
\text { 6. } & \text { Emotional role functioning } \\
\text { 7. } & \text { Social role functioning } \\
\text { 8. } & \text { Mental health } \\
\end{array}$ & $\begin{array}{l}\text { Self-administered } \\
\qquad 10 \pm 8 \mathrm{~min}\end{array}$ & $\begin{array}{l}\text { Higher scores indicate better HRQoL } \\
\text { The correct calculation of SF- } 36 \text { requires } \\
\text { the use of special algorithms, which are } \\
\text { strictly controlled by a private company * }\end{array}$ \\
\hline $\begin{array}{c}\text { Euroqol } 5 \text { dimensions } \\
\text { EQ-5D// }\end{array}$ & $\begin{array}{l}\text { 1. Mobility } \\
\text { 2. Self-care } \\
\text { 3. Usual activities } \\
\text { 4. Pain/discomfort } \\
\text { 5. Anxiety/depression } \\
\text { and additional perceived health status } \\
\text { measured through a visual-analogue } \\
\text { scale (VAS) }\end{array}$ & $\begin{array}{l}\text { Self-administered } \\
5 / 10 \mathrm{~min} .\end{array}$ & $\begin{array}{l}\text { Two scores, one for the } 5 \text { domains and } \\
\text { another for the VAS. } \\
5 \text { domains score: } 1- \\
\text { scores indicate worse HRQoL } \\
\text { VAS score: } 0-100 \\
\text { Higher scores indicate better HRQoL }\end{array}$ \\
\hline $\begin{array}{c}\text { World Health Organization } \\
\text { Quality of Life questionnaire } \\
\text { WHOQOL-100 } \\
100 \text { items }\end{array}$ & $\begin{array}{ll}\text { 1. } & \text { Physical Health } \\
\text { 2. } & \text { Psychological } \\
\text { 3. } & \text { Level of Independence } \\
\text { 4. } & \text { Social Relations } \\
\text { 5. } & \text { Environment } \\
\text { 6. } & \text { Spirituality/Religion/Personal beliefs }\end{array}$ & $\begin{array}{l}\text { Self-administered if respondents } \\
\text { have sufficient ability: otherwise, } \\
\text { interviewer assisted/administered } \\
30 \mathrm{~min} .\end{array}$ & $\begin{array}{l}\text { Produces scores relating to particular } \\
\text { facets of QoL, scores relating to larger } \\
\text { domains and a score relating to overall } \\
\text { QoL and general health. } \\
\text { Higher scores indicate better HRQoL * }\end{array}$ \\
\hline $\begin{array}{c}\text { World Health Organization } \\
\text { Quality of Life questionnaire } \\
\text { WHOQOL-BREF } \\
26 \text { items }\end{array}$ & $\begin{array}{ll}\text { 1. } & \text { Physical health } \\
\text { 2. } & \text { Psychological } \\
\text { 3. } & \text { Social relationships } \\
\text { 4. } & \text { Environment }\end{array}$ & $\begin{array}{c}\text { Self-administered if respondents } \\
\text { have sufficient ability: otherwise, } \\
\text { interviewer assisted/administered } \\
\text { 10/15 min. }\end{array}$ & $\begin{array}{l}\text { Produces a quality of life profile. It is } \\
\text { possible to derive four domain scores. } \\
\text { Higher scores indicate better HRQoL }\end{array}$ \\
\hline
\end{tabular}


Table 2. Cont.

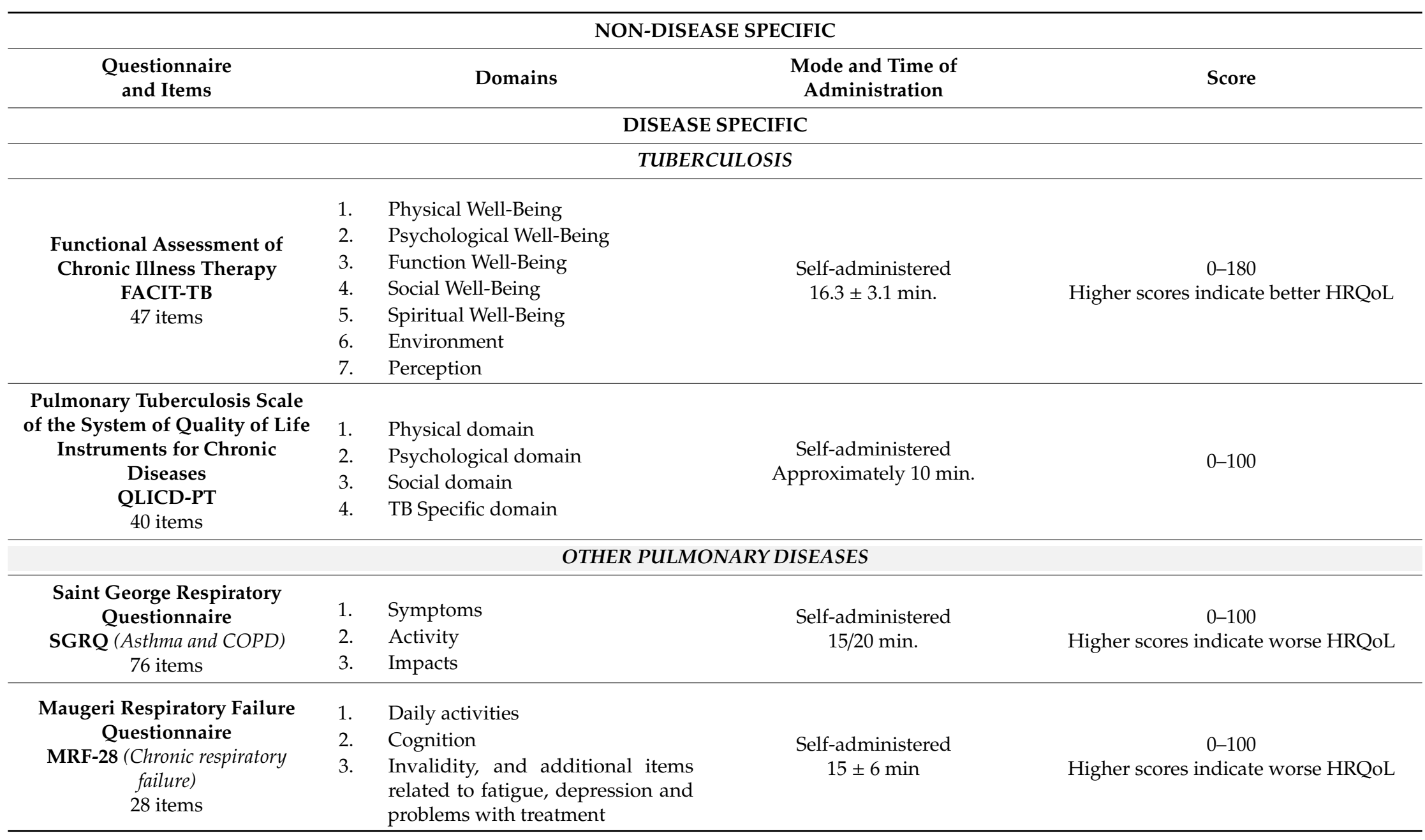


Table 2. Cont.

\begin{tabular}{|c|c|c|c|}
\hline \multicolumn{4}{|c|}{ NON-DISEASE SPECIFIC } \\
\hline $\begin{array}{c}\text { Questionnaire } \\
\text { and Items }\end{array}$ & Domains & $\begin{array}{l}\text { Mode and Time of } \\
\text { Administration }\end{array}$ & Score \\
\hline $\begin{array}{c}\text { Quality of Life-Bronchiectasis } \\
\text { QOL-B (Non CF-Bronchiectasis) } \\
37 \text { items }\end{array}$ & $\begin{array}{ll}\text { 1. } & \text { Respiratory Symptoms } \\
\text { 2. } & \text { Physical } \\
\text { 3. } & \text { Role } \\
\text { 4. } & \text { Emotional } \\
\text { 5. } & \text { Social Functioning } \\
\text { 6. } & \text { Vitality, } \\
\text { 7. } & \text { Health Perceptions } \\
\text { 8. } & \text { Treatment Burden } \\
\end{array}$ & $\begin{array}{l}\text { Self-administered } \\
\quad 4-5 \text { min. }\end{array}$ & $\begin{array}{l}\qquad 0-100 \\
\text { Higher scores indicate better HRQoL }\end{array}$ \\
\hline $\begin{array}{c}\text { Asthma Quality of Life } \\
\text { Questionnaire } \\
\text { AQLQ } \\
\text { (Asthma) } \\
32 \text { items }\end{array}$ & $\begin{array}{ll}\text { 1. } & \text { Symptoms } \\
\text { 2. } & \text { Activity Limitation } \\
\text { 3. } & \text { Emotional Function } \\
\text { 4. } & \text { Environmental Exposure }\end{array}$ & $\begin{array}{l}\text { Self-administered } \\
\quad 4-5 \text { min. }\end{array}$ & $\begin{array}{l}\qquad 1-7 \\
\text { Higher scores indicate better HRQoL }\end{array}$ \\
\hline
\end{tabular}




\subsection{Pulmonary Rehabilitation}

Pulmonary rehabilitation is a non-pharmacological intervention aimed at improving the physical and psychological conditions of individuals affected by chronic lung diseases [46]. It includes different interventions including, among others, the integration of an optimised medical treatment (drugs, Long-Term Oxygen Therapy-LTOT, ventilation) with physiotherapy, exercise training, education, and behavioural changes $[39,43,44]$.

\subsubsection{LTOT and Ventilation}

The importance of LTOT and mechanical ventilation in supporting the management of post-TB treatment sequelae is well known [44]. Intermittent positive pressure ventilation through a nasal mask (NIPPV) applied during exercise in patients with pulmonary TB sequelae improved arterial blood gas measurements, reduced breathlessness, and increased exercise tolerance [47]. The use of a poncho (wraparound) ventilator and mouth intermittent positive pressure ventilation (MIPPV) was studied, showing beneficial results [48].

\subsubsection{Physiotherapy}

The role of physiotherapy in expectorating secretions is well known and largely utilised [44]. Mechanical methods of vibration massage have been proposed to prevent early post-resectional complications (atelectasis, non-specific pneumonia, residual post-resection pleural cavity, and bronchial fistulas) after surgical interventions for TB and to improve the functional status [49].

\subsubsection{Exercise Training}

Post TB sequelae may cause obstructive or restrictive damage and decrease the effort tolerance [50]. Patients undergoing long and/or multiple rounds of treatment may suffer from cachexia, asthenia, and muscle fatigue [44]. Before initiating a specific rehabilitation programme, patients should undergo a complete lung functional assessment, including spirometry and exercise capacity testing to enable an appropriate exercise training regime. Exercise capacity is usually based on cardiopulmonary exercise testing or walking tests (6MWT, incremental shuttle walking test (ISWT)) in order to set physical training sessions that exceed the physical loads of daily life activities [45,51-58]. Some studies documented the positive role of aerobic training on symptoms, anxiety, depression, and QoL [45,51-58].

\subsubsection{Education and Psychological Counselling}

Education about lung disease and its management is an important aspect of pulmonary rehabilitation [43-45]. It implies that specialists teach patients about respiratory diseases and support them through self-management training. Knowledge about the disease helps patients to understand, recognize, and treat their symptoms in order to achieve a better control of the disease in daily life. It may consist of one or more interventions, including smoking cessation, oxygen therapy, nutrition, physical activity, and the proper use of medications [43-45].

Psychological support is extremely important because depression and anxiety are often associated with TB and may contribute to fatigue and reduce physical activity. Psychological counselling should be offered either individually or in small groups as discussion will enable patients to feel more comfortable with their disease and favour their participation in social activities [43-45]

\subsection{Effectiveness of Pulmonary Rehabilitation in $T B$}

The available information on the effectiveness of rehabilitation is summarised in Table 3. 
Table 3. Summary of studies reporting pre/post pulmonary rehabilitation (PR) interventions and their effects on outcome measures in post-TB sequelae patients.

\begin{tabular}{|c|c|c|c|c|c|c|c|}
\hline \multirow{2}{*}{$\begin{array}{c}\text { Author, Year; } \\
\text { [Ref] } \\
\text { Country } \\
\end{array}$} & \multirow{2}{*}{ Reference } & \multirow{2}{*}{$\begin{array}{c}\text { Study Population } \\
\text { Design } \\
\text { Lung Function and Exercise Tests } \\
\text { PR Duration and Setting } \\
\end{array}$} & \multicolumn{2}{|c|}{ Outcome Measures Significantly Improved } & \multicolumn{2}{|c|}{ Outcome Measures Not Significantly Improved } & \multirow{2}{*}{$\begin{array}{c}\text { Gain in 6MWT or } \\
\text { ISWT } \\
\text { (meters/m) }\end{array}$} \\
\hline & & & LFT & $\begin{array}{l}\text { Exercise Capacity } \\
\text { and QoL }\end{array}$ & LFT & Exercise Capacity and QoL & \\
\hline Visca, 2019, Italy & [45] & $\begin{array}{c}43 \text { patients; } \\
\text { Retrospective study } \\
\text { Spirometry, BGA, 6MWT } \\
\text { Spontaneous walking } \mathrm{SpO}_{2} \\
\text { 3 weeks, inpatient }\end{array}$ & $\begin{array}{l}\text { FEV1 } \\
\text { LFEV1\% } \\
\text { FVC\% } \\
\mathrm{PaO}_{2} \\
\mathrm{SaO}_{2}\end{array}$ & $\begin{array}{c}\text { 6MWD m } \\
\text { 6MWD \% } \\
\mathrm{HR} \text { average } \\
\mathrm{SpO}_{2} \text { average (6MWT) } \\
\mathrm{SpO}_{2} \text { min (6MWT) } \\
\text { Modified Borg dyspnoea } \\
\text { final } \\
\text { Modified Borg fatigue } \\
\text { final } \\
\mathrm{SpO}_{2} \text { baseline (SW) } \\
\mathrm{SpO}_{2} \text { min (SW) }\end{array}$ & $\begin{array}{c}\mathrm{FVC} \mathrm{L}^{*} \\
\mathrm{FEV} 1 / \mathrm{FVC}{ }^{*} \\
\mathrm{RV}^{\wedge} \\
\mathrm{PaCO}_{2}^{*} \\
\mathrm{pH}^{\wedge} \mathrm{FiO}_{2}{ }^{\wedge}(\mathrm{BGA})\end{array}$ & $\begin{array}{c}\text { HR baseline }^{\wedge} \\
\text { HR max } \\
\mathrm{SpO}_{2} \text { baseline }(6 \mathrm{MWT})^{\wedge} \\
\text { Modified Borg dyspnoea baseline } \\
\\
\text { Modified Borg fatigue baseline ^ } \\
\mathrm{SpO}_{2} \text { baseline }(\mathrm{SW})^{*} \\
\mathrm{FiO}_{2}{ }^{\wedge}(6 \mathrm{MWT}, \mathrm{SW})\end{array}$ & $+35 \mathrm{~m}$ \\
\hline $\begin{array}{l}\text { Tada, 2002, } \\
\text { Japan }\end{array}$ & [51] & $\begin{array}{c}\text { 37 patients } \\
\text { Study design \# } \\
\text { Spirometry, BGA, 6MWT, Pimax, QoL } \\
\text { 3.9 weeks, inpatient }\end{array}$ & $\begin{array}{l}\mathrm{VCL} \\
\mathrm{FEV} 1 \mathrm{~L} \\
\mathrm{PaO}_{2} \\
\mathrm{Pimax}\end{array}$ & $\begin{array}{c}\text { 6MWD m } \\
\text { Dyspnoea } \\
\text { QoL }\end{array}$ & $-\#$ & $-\#$ & $+36 \mathrm{~m}$ \\
\hline $\begin{array}{l}\text { Jones, 2017, } \\
\text { Uganda }\end{array}$ & [52] & $\begin{array}{c}29 \text { patients } \\
\text { Prospective study } \\
\text { Spirometry (baseline only), ISWT } \\
\text { Sit-to-Stand, BMI, Mid upper arm } \\
\text { circumference, QoL } \\
6 \text { weeks, outpatient and homebased }\end{array}$ & $\begin{array}{c}\text { BMI }\left(\mathrm{kg} / \mathrm{m}^{2}\right) \\
\text { Mid upper arm } \\
\text { circumference }(\mathrm{cm})\end{array}$ & $\begin{array}{c}\text { ISWT (m) } \\
\text { Borg score after ISWT } \\
\text { Sit-to-stand time (seconds) } \\
\text { CCQ total score } \\
\text { CCQ symptom score } \\
\text { CCQ mental state score } \\
\text { CCQ functional state } \\
\text { scoreP } \\
\text { HQ-9 total score } \\
\text { Karnofsky score }\end{array}$ & Not specified & Not specified & $+90 \mathrm{~m}$ \\
\hline Ando, 2003, Japan & [53] & $\begin{array}{c}32 \text { patients } \\
\text { Prospective non randomized open } \\
\text { trial } \\
\text { Spirometry, BGA, 6MWT, HRQL } \\
9 \text { weeks, outpatient }\end{array}$ & VC L & $\begin{array}{l}\text { 6MWD m } \\
\text { TDI } \\
\text { MRC } \\
\text { ADL }\end{array}$ & $\begin{array}{l}\mathrm{FEV} 1 \mathrm{~L}^{*} \\
\mathrm{PaO}_{2}{ }^{*} \\
\mathrm{PaCO}_{2}\end{array}$ & Not specified & $+42 \mathrm{~m}$ \\
\hline Singh, 2018, India & [54] & $\begin{array}{c}29 \text { patients } \\
\text { Prospective cohort study } \\
\text { Spirometry, 6MWT, HRQL } \\
8 \text { weeks, inpatient }\end{array}$ & Not specified & $\begin{array}{c}\text { 6MWD m } \\
\text { CRQ }\end{array}$ & $\begin{array}{l}\text { FEV1 L* } \\
\text { FVC L* } \\
\text { FEV1/FVC^ }\end{array}$ & MMRC * & $+38 \mathrm{~m}$ \\
\hline
\end{tabular}


Table 3. Cont.

\begin{tabular}{|c|c|c|c|c|c|c|c|}
\hline \multirow{2}{*}{$\begin{array}{l}\text { Author, Year; } \\
\text { [Ref] } \\
\text { Country }\end{array}$} & \multirow{2}{*}{ Reference } & \multirow{2}{*}{$\begin{array}{c}\text { Study Population } \\
\text { Design } \\
\text { Lung Function and Exercise Tests } \\
\text { PR Duration and Setting } \\
\end{array}$} & \multicolumn{2}{|c|}{ Outcome Measures Significantly Improved } & \multicolumn{2}{|c|}{ Outcome Measures Not Significantly Improved } & \multirow{2}{*}{$\begin{array}{c}\text { Gain in 6MWT or } \\
\text { ISWT } \\
\text { (meters/m) }\end{array}$} \\
\hline & & & LFT & $\begin{array}{l}\text { Exercise Capacity } \\
\text { and QoL }\end{array}$ & LFT & Exercise Capacity and QoL & \\
\hline $\begin{array}{l}\text { Yoshida, 2006, } \\
\text { Japan }\end{array}$ & [55] & $\begin{array}{c}10 \text { patients } \\
\text { Observational study } \\
\text { Spirometry, BGA, treadmill test } \\
\text { 6MWT } \\
\text { 3 weeks, inpatient }\end{array}$ & Not specified & $\begin{array}{c}\mathrm{VO}_{2} \text { peak (Treadmill) } \\
\text { 6MWD m }\end{array}$ & $\begin{array}{l}\mathrm{VCL} \mathrm{L}^{\wedge} \\
\mathrm{VC} \% \\
\mathrm{FEV} 1 \mathrm{~L}^{\wedge} \\
\mathrm{FEV} 1 / \mathrm{FVC} \% \\
\mathrm{MVVL}^{*} \\
\mathrm{PaO}_{2}^{*} \\
\mathrm{PaCO}_{2}{ }^{*} \\
\mathrm{pH}^{\wedge}\end{array}$ & $\begin{array}{c}\text { Treadmill: } \\
\text { VEmax L/min } \\
\text { VEmax/MVV }{ }^{*} \\
\text { HRmax } \\
{ }^{\wedge} \\
\text { Modified Borg dyspnoea final }{ }^{*} \\
\text { Modified Borg fatigue final }{ }^{*} \\
\text { 6MWT: } \\
\text { SpO }{ }^{\wedge}{ }^{\wedge} \\
\text { Pulse rate } \\
\text { Modified Borg dyspnoea final * } \\
\text { Modified Borg fatigue final }{ }^{*}\end{array}$ & $+68 \mathrm{~m}$ \\
\hline $\begin{array}{l}\text { Wilches, 2009, } \\
\text { Colombia } \\
\text { (Case report) }\end{array}$ & [56] & $\begin{array}{c}1 \text { patient } \$ \\
\text { Case report } \\
\text { Spirometry, BGA,6MWT, HRQL } \\
32 \text { weeks, inpatient }\end{array}$ & Not specified & Not specified & Not specified & $\begin{array}{c}\text { 6MWD* } \\
\text { HADS* } \\
\text { SF36* } \\
\text { MRC * } \\
\text { Borg dyspnoea final * }\end{array}$ & $+110 \mathrm{~m}$ \\
\hline $\begin{array}{c}\text { Betancourt-Peña, } \\
\text { 2015, } \\
\text { Colombia }\end{array}$ & [57] & $\begin{array}{c}\text { 11 patients } \\
\text { Quasi-experimental study } \\
\text { Spirometry (baseline only) 6MWT } \\
\text { BMI, HRQL } \\
\text { 8 weeks, outpatient }\end{array}$ & Not specified & $\begin{array}{c}\text { 6MWD } \\
\mathrm{VO}_{2} \text { peak (Treadmill) } \\
\text { SGRQ } \\
\text { HADS }\end{array}$ & $\operatorname{BMI}\left(\mathrm{kg} / \mathrm{m}^{2}\right)^{*}$ & $\begin{array}{c}\mathrm{SpO}_{2} \text { baseline }^{\wedge} \\
\mathrm{SpO}_{2} \text { final } \\
\text { 6MWT desaturation } \\
\mathrm{MRC}^{*}\end{array}$ & $+110.2 \mathrm{~m}$ \\
\hline $\begin{array}{l}\text { Rivera Motta, 2016, } \\
\text { Colombia } \\
\text { (conference } \\
\text { abstract) }\end{array}$ & [58] & $\begin{array}{c}\text { 8 patients } \\
\text { Spirometry, 6MWT, Treadmill test } \\
\text { QoL } \\
\text { 8 weeks, inpatient }\end{array}$ & Not specified & $\begin{array}{c}\mathrm{VO}_{2} \text { peak (Treadmill) } \\
\text { 6MWD m } \\
\text { SF36 } \\
\text { SGRQ }\end{array}$ & Not specified & Not specified & +63.6 \\
\hline \multicolumn{8}{|c|}{ 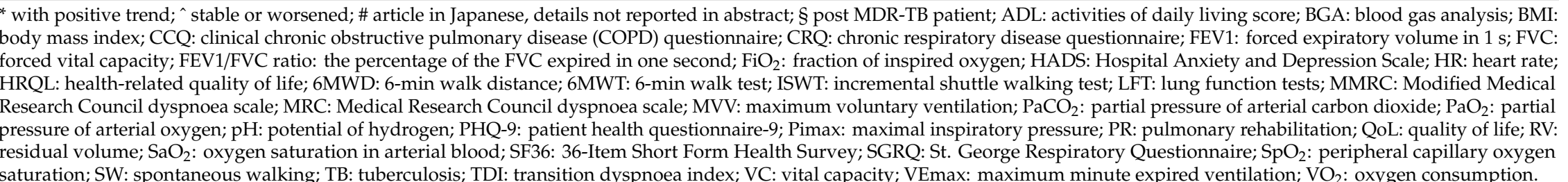 } \\
\hline
\end{tabular}


In the vast majority of the studies, the spirometry parameters, oxygen saturation, and exercise capacity tests (6MWT or ISWT, range 35-110 m) improved significantly. When QoL tests were performed, they also improved significantly [45,51-58]. Unfortunately the different studies reported different parameters, making a meta-analytic evaluation difficult.

\subsection{Priorities for Research}

A comprehensive review on TB and rehabilitation [44] recommended that future studies investigating pulmonary rehabilitation include the following information to ensure comparative analyses:

a) Patients' characteristics (age, sex, ethnicity, etc);

b) A description of the TB disease, (history of previous treatment, bacteriological status, drug-resistance profile, treatment history -drugs and regimens; and adverse events observed) $[7,8]$;

c) The physiopathological status, spirometry with response to bronchodilator, assessment of lung volumes through plethysmography, DLCO, arterial blood gas analysis, 6MWT, radiological evaluation-ideally a computerized tomography (CT) scan, a QoL evaluation with both general and a specific tools (St. George's questionnaire);

d) Rationale and design of the pulmonary rehabilitation plan, with a pre-/post-test comparison;

e) Cost-assessment and evaluation of programmatic feasibility [59].

\section{Conclusions}

This review describes the evidence available on adjuvant surgery (as described in the most important recent guidelines), as well as on the diagnosis and management of patients with post-treatment sequelae. The initial evidence supports the importance of adequate functional evaluations of these patients, which is necessary to identify those who will benefit from pulmonary rehabilitation.

A collection of high-quality standardised variables would allow the research to advance in the understanding of the need for, and the effectiveness of, pulmonary rehabilitation both at the individual and at the programmatic level.

Author Contributions: Conceptualization, D.V., S.T. and G.B.M.; methodology, R.C., L.D., G.B.M.; data curation, E.P., R.C., D.V.; Tables and Figure conceptualization: E.P., D.V., R.C., E.Z., G.B.M.; writing-original draft preparation, all authors; surgery: A.W.M.; Functional evaluation and rehabilitation: D.V., E.Z., A.S.; Public health aspects: M.v.s.B.; overall writing-review and editing, all authors; supervision, G.B.M. All authors have read and agreed to the published version of the manuscript.

Funding: This research received no external funding.

Acknowledgments: The article is part of the activities of the Global Tuberculosis Network (GTN; Committees on TB Treatment, Working Group on Pulmonary Rehabilitation and Global TB Consilium) and of the WHO Collaborating Centre for Tuberculosis and Lung Diseases, Tradate, ITA-80, 2017-2020- GBM/RC/LDA).

Conflicts of Interest: The authors declare no conflict of interest.

\section{References}

1. Lönnroth, K.; Migliori, G.B.; Abubakar, I.; D'Ambrosio, L.; de Vries, G.; Diel, R.; Douglas, P.; Falzon, D.; Gaudreau, M.A.; Goletti, D.; et al. Towards tuberculosis elimination: An action framework for low-incidence countries. Eur. Respir. J. 2015, 45, 928-952. [CrossRef]

2. Migliori, G.B.; Tiber, I.S.; Zumla, A.; Petersen, E.; Chakaya, J.M.; Wejse, C.; Muñoz Torrico, M.; Duarte, R.; Alffenaar, J.W.; Members of the Global Tuberculosis Network; et al. MDR/XDR-TB management of patients and contacts: Challenges facing the new decade. The 2020 clinical update by the Global Tuberculosis Network. Int. J. Infect. Dis. 2020, S1201-9712(20)30045-X. [CrossRef] 
3. Lange, C.; Aarnoutse, R.E.; Alffenaar, J.W.C.; Bothamley, G.; Brinkmann, F.; Costa, J.; Chesov, D.; van Crevel, R.; Dedicoat, M.; Dominguez, J.; et al. Management of patients with multidrug-resistant tuberculosis. Int. J. Tuberc. Lung. Dis. 2019, 23, 645-662. [CrossRef] [PubMed]

4. Pontali, E.; Tadolini, M.; Migliori, G.B. TB consilia and quality of tuberculosis management. Int. J. Tuberc. Lung. Dis. 2019, 23, 1048-1049. [CrossRef] [PubMed]

5. World Health Organization. Global Tuberculosis Report 2019; WHO/CDS/TB/2019.15; World Health Organization: Geneva, Switzerland, 2019; Available online: https://apps.who.int/iris/bitstream/handle/ 10665/329368/9789241565714-eng.pdf?ua=1 (accessed on 26 February 2020).

6. Borisov, S.E.; Dheda, K.; Enwerem, M.; Romero Leyet, R.; D'Ambrosio, L.; Centis, R.; Sotgiu, G.; Tiberi, S.; Alffenaar, J.W.; Maryandyshev, A.; et al. Effectiveness and safety of bedaquiline-containing regimens in the treatment of MDR- and XDR-TB: A multicentre study. Eur. Respir. J. 2017, 49, 1700387. [CrossRef]

7. Akkerman, O.; Aleksa, A.; Alffenaar, J.W.; Al-Marzouqi, N.H.; Arias-Guillén, M.; Belilovski, E.; Bernal, E.; Boeree, M.J.; Borisov, S.E.; Bruchfeld, J.; et al. Members of the International Study Group on new anti-tuberculosis drugs and adverse events monitoring. Surveillance of adverse events in the treatment of drug-resistant tuberculosis: A global feasibility study. Int. J. Infect. Dis. 2019, 83, 72-76. [CrossRef]

8. Borisov, S.; Danila, E.; Maryandyshev, A.; Dalcolmo, M.; Miliauskas, S.; Kuksa, L.; Manga, S.; Skrahina, A.; Diktanas, S.; Codecasa, L.R.; et al. Surveillance of adverse events in the treatment of drug-resistant tuberculosis: First global report. Eur. Respir. J. 2019, 54, 1901522. [CrossRef]

9. Pontali, E.; Raviglione, M.C.; Migliori, G.B.; writing group members of the Global TB Network Clinical Trials Committee. Regimens to treat multidrug-resistant tuberculosis: Past, present and future perspectives. Eur. Respir. Rev. 2019, 28, 190035. [CrossRef]

10. Pontali, E.; Sotgiu, G.; Tiberi, S.; Tadolini, M.; Visca, D.; D’Ambrosio, L.; Centis, R.; Spanevello, A.; Migliori, G.B. Combined treatment of drug-resistant tuberculosis with bedaquiline and delamanid: A systematic review. Eur. Respir. J. 2018, 52, 1800934. [CrossRef]

11. Pontali, E.; D’Ambrosio, L.; Centis, R.; Sotgiu, G.; Migliori, G.B. Multidrug-resistant tuberculosis and beyond: An updated analysis of the current evidence on bedaquiline. Eur. Respir. J. 2017, 49, 1700146. [CrossRef]

12. Pontali, E.; Sotgiu, G.; D'Ambrosio, L.; Centis, R.; Migliori, G.B. Bedaquiline and MDR-TB: A systematic and critical analysis of the evidence. Eur. Respir. J. 2016, 47, 394-402. [CrossRef] [PubMed]

13. Migliori, G.B.; Nardell, E.; Yedilbayev, A.; D'Ambrosio, L.; Centis, R.; Tadolini, M.; van den Boom, M.; Ehsani, S.; Sotgiu, G.; Dara, M. Reducing tuberculosis transmission: A consensus document from the World Health Organization Regional Office for Europe. Eur. Respir. J. 2019, 53, 1900391. [CrossRef] [PubMed]

14. Akkerman, O.W.; Ter Beek, L.; Centis, R.; Maeurer, M.; Visca, D.; Muñoz-Torrico, M.; Tiberi, S.; Migliori, G.B. Rehabilitation, optimized nutritional care, and boosting host internal milieu to improve long-term treatment outcomes in tuberculosis patients. Int. J. Infect. Dis. 2020, S1201-9712(20)30031-X. [CrossRef] [PubMed]

15. Chan, E.D.; Iseman, M.D. Surgery for MDR-TB? Int. J. Tuberc. Lung. Dis. 2013, 17, 710. [CrossRef] [PubMed]

16. Chan, E.D.; Laurel, V.; Strand, M.J.; Chan, J.F.; Huynh, M.L.; Goble, M.; Iseman, M.D. Treatment and outcome analysis of 205 patients with multidrug-resistant tuberculosis. Am. J. Respir. Crit. Care Med. 2004, 169, 1103-1109. [CrossRef]

17. Iseman, M. Treatment of multidrug-resistant tuberculosis. N. Engl. J. Med. 1993, 329, 784.

18. Iseman, M.D.; Madsen, L.; Goble, M.; Pomerantz, M. Surgical intervention in the treatment of pulmonary disease caused by drug resistant Mycobacterium tuberculosis. Am. Rev. Respir. Dis. 1990, 141, 623. [CrossRef]

19. Dara, M.; Sotgiu, G.; Zaleskis, R.; Migliori, G.B. Untreatable tuberculosis: Is surgery the answer? Eur. Respir. J. 2015, 45, 577-582. [CrossRef]

20. Borisov, S.E.; D’Ambrosio, L.; Centis, R.; Tiberi, S.; Dheda, K.; Alffenaar, J.W.; Amale, R.; Belilowski, E.; Bruchfeld, J.; Canneto, B.; et al. Outcomes of patients with drug-resistant-tuberculosis treated with bedaquiline-containing regimens and undergoing adjunctive surgery. J. Infect. 2019, 78, 35-39. [CrossRef]

21. Tiberi, S.; Torrico, M.M.; Rahman, A.; Krutikov, M.; Visca, D.; Silva, D.R.; Kunst, H.; Migliori, G.B. Managing severe tuberculosis and its sequelae: From intensive care to surgery and rehabilitation. J. Bras. Pneumol. 2019, 45, e20180324. [CrossRef]

22. Calligaro, G.L.; Moodley, L.; Symons, G.; Dheda, K. The medical and surgical treatment of drug-resistant tuberculosis. J. Thorac. Dis. 2014, 6, 186-195. [PubMed] 
23. Subotic, D.; Yablonskiy, P.; Sulis, G.; Cordos, I.; Petrov, D.; Centis, R.; D'Ambrosio, L.; Sotgiu, G.; Migliori, G.B. Surgery and pleuro-pulmonary tuberculosis: A scientific literature review. J. Thorac. Dis. 2016, 8, E474-E485. [CrossRef] [PubMed]

24. Sayir, F.; Ocakcioglu, I.; Şehitoğulları, A.; Çobanoğlu, U. Clinical analysis of pneumonectomy for destroyed lung: A retrospective study of 32 patients. Gen. Thorac. Cardiovasc. Surg. 2019, 67, 530-536. [CrossRef] [PubMed]

25. Yablonskii, P.K.; Kudriashov, G.G.; Avetisyan, A.O. Surgical Resection in the Treatment of Pulmonary Tuberculosis. Thorac. Surg. Clin. 2019, 29, 37-46. [CrossRef] [PubMed]

26. Chen, G.; Zhong, F.M.; Xu, X.D.; Yu, G.C.; Zhu, P.F. Efficacy of regional arterial embolization before pleuropulmonary resection in 32 patients with tuberculosis-destroyed lung. Bmc. Pulm. Med. 2018, 18, 156. [CrossRef]

27. Giller, D.B.; Giller, B.D.; Giller, G.V.; Shcherbakova, G.V.; Bizhanov, A.B.; Enilenis, I.I.; Glotov, A.A. Treatment of pulmonary tuberculosis: Past and present. Eur. J. Cardiothorac. Surg. 2018, 53, 967-972. [CrossRef]

28. Marrone, M.T.; Venkataramanan, V.; Goodman, M.; Hill, A.C.; Jereb, J.A.; Mase, S.R. Surgical interventions for drug-resistant tuberculosis: A systematic review and metaanalysis. Int. J. Tuberc. Lung. Dis. 2013, 17, 6-16. [CrossRef]

29. Xu, H.B.; Jiang, R.H.; Li, L. Pulmonary resection for patients with multidrug-resistant tuberculosis: Systematic review and meta-analysis. J. Antimicrob. Chemother. 2011, 66, 1687-1695. [CrossRef]

30. Johnston, J.C.; Shahidi, N.C.; Sadatsafavi, M.; Fitzgerald, J.M. Treatment outcomes of multidrug-resistant tuberculosis: A systematic review and meta-analysis. PLoS ONE 2009, 4, e6914. [CrossRef]

31. Orenstein, E.W.; Basu, S.; Shah, N.S.; Andrews, J.R.; Friedland, G.H.; Moll, A.P.; Gandhi, N.R.; Galvani, A.P. Treatment outcomes among patients with multidrug-resistant tuberculosis: Systematic review and meta-analysis. Lancet. Infect. Dis. 2009, 9, 153-161. [CrossRef]

32. Hannink, G.; Gooszen, H.G.; van Laarhoven, C.J.; Rovers, M.M. A systematic review of individual patient data meta-analyses on surgical interventions. Syst. Rev. 2013, 2, 52. [CrossRef] [PubMed]

33. Collaborative Group for the Meta-Analysis of Individual Patient Data in MDR-TB treatment-2017; Ahmad, N.; Ahuja, S.D.; Akkerman, O.W.; Alffenaar, J.C.; Anderson, L.F.; Baghaei, P.; Bang, D.; Barry, P.M.; Bastos, M.L.; et al. Treatment correlates of successful outcomes in pulmonary multidrug-resistant tuberculosis: An individual patient data meta-analysis. Lancet 2018, 392, 821-834. [CrossRef]

34. Campbell, J.R.; Falzon, D.; Mirzayev, F.; Jaramillo, E.; Migliori, G.B.; Mitnick, C.D.; Ndjeka, N.; Menzies, D. Improving Quality of Patient Data for Treatment of Multidrug- or Rifampin-Resistant Tuberculosis. Emerg. Infect. Dis. 2020, 26, 2020. [CrossRef] [PubMed]

35. Fox, G.J.; Mitnick, C.D.; Benedetti, A.; Chan, E.D.; Becerra, M.; Chiang, C.Y.; Keshavjee, S.; Koh, W.J.; Shiraishi, Y.; Viiklepp, P.; et al. Surgery as an Adjunctive Treatment for Multidrug-Resistant Tuberculosis: An Individual Patient Data Metaanalysis. Clin. Infect. Dis. 2016, 62, 887-895. [CrossRef]

36. World Health Organization. WHO Consolidated Guidelines on Drug-Resistant Tuberculosis Treatment; WHO/CDS/TB/2019.7; World Health Organization: Geneva, Switzerland, 2019; Available online: https: //apps.who.int/iris/bitstream/handle/10665/311389/9789241550529-eng.pdf?ua=1 (accessed on 26 February 2020).

37. World Health Organization Regional Office for Europe. The Role of Surgery in the Treatment of Pulmonary TB and Multidrug and Extensively Drug-Resistant TB; WHO Regional Office for Europe: Copenhagen, Denmark, 2014; Available online: http://www.euro.who.int/_data/assets/pdf_file/0005/259691/The-role-of-surgery-inthe-treatment-of-pulmonary-TB-and-multidrug-and-extensively-drug-resistant-TB.pdf?ua=1 (accessed on 26 February 2020).

38. Caminero, J.A. (Ed.) Guidelines for Clinical and Operational Management of Drug-Resistant Tuberculosis; International Union Against Tuberculosis and Lung Disease: Paris, France, 2013; pp. 1-232.

39. Nahid, P.; Mase, S.R.; Migliori, G.B.; Sotgiu, G.; Bothamley, G.H.; Brozek, J.L.; Cattamanchi, A.; Cegielski, J.P.; Chen, L.; Daley, C.L.; et al. Treatment of Drug-Resistant Tuberculosis. An Official ATS/CDC/ERS/IDSA Clinical Practice Guideline. Am. J. Respir. Crit. Care. Med. 2019, 200, e93-e142. [CrossRef]

40. Marfina, G.Y.; Vladimirov, K.B.; Avetisian, A.O.; Starshinova, A.A.; Kudriashov, G.G.; Sokolovich, E.G.; Yablonskii, P.K. Bilateral cavitary multidrug- or extensively drug-resistant tuberculosis: Role of surgery. Eur. J. Cardiothorac. Surg. 2018, 53, 618-624. [CrossRef]

41. Pasipanodya, J.G.; Miller, T.L.; Vecino, M.; Munguia, G.; Garmon, R.; Bae, S.; Drewyer, G.; Weis, S.E. Pulmonary impairment after tuberculosis. Chest 2007, 131, 1817-1824. [CrossRef] 
42. Hnizdo, E.; Singh, T.; Churchyard, G. Chronic pulmonary function impairment caused by initial and recurrent pulmonary tuberculosis following treatment. Thorax 2000, 55, 32-38. [CrossRef]

43. Muñoz-Torrico, M.; Cid-Juárez, S.; Galicia-Amor, S.; Troosters, T.; Spanevello, A. Sequelae Assessment and Rehabilitation. In Tuberculosis (ERSMonograph); Migliori, G.B., Bothamley, G., Duarte, R., Rendon, A., Eds.; European Respiratory Society: Sheffield, UK, 2018; pp. 326-342. [CrossRef]

44. Muñoz-Torrico, M.; Rendon, A.; Centis, R.; D'Ambrosio, L.; Fuentes, Z.; Torres-Duque, C.; Mello, F.; Dalcolmo, M.; Pérez-Padilla, R.; Spanevello, A.; et al. Is there a rationale for pulmonary rehabilitation following successful chemotherapy for tuberculosis? J. Bras. Pneumol. 2016, 42, 374-385. [CrossRef]

45. Visca, D.; Zampogna, E.; Sotgiu, G.; Centis, R.; Saderi, L.; D’Ambrosio, L.; Pegoraro, V.; Pignatti, P.; Muňoz-Torrico, M.; Migliori, G.B.; et al. Pulmonary rehabilitation is effective in patients with tuberculosis pulmonary sequelae. Eur. Respir. J. 2019, 53, 1802184. [CrossRef]

46. Spruit, M.A.; Singh, S.J.; Garvey, C.; ZuWallack, R.; Nici, L.; Rochester, C.; Hill, K.; Holland, A.E.; Lareau, S.C.; Man, W.D.; et al. ATS/ERS Task Force on Pulmonary Rehabilitation. An official American Thoracic Society/European Respiratory Society statement: Key concepts and advances in pulmonary rehabilitation. Am. J. Respir. Crit. Care. Med. 2013, 188, e13-e64. [CrossRef] [PubMed]

47. Tsuboi, T.; Ohi, M.; Chin, K.; Hirata, H.; Otsuka, N.; Kita, H.; Kuno, K. Ventilatory support during exercise in patients with pulmonary tuberculosis sequelae. Chest 1997, 112, 1000-1007. [CrossRef] [PubMed]

48. Yang, G.F.; Alba, A.; Lee, M. Respiratory rehabilitation in severe restrictive lung disease secondary to tuberculosis. Arch. Phys. Med. Rehabil. 1984, 65, 556-558. [PubMed]

49. Strelis, A.A.; Strelis, A.K.; Roskoshnykh, V.K. Vibration massage in the prevention of postresection complications and in the clinical rehabilitation of patients with pulmonary tuberculosis after surgical interventions. Probl. Tuberk. Bolezn. Legk. 2004, 11, 29-34.

50. Daniels, K.J.; Irusen, E.; Pharaoh, H.; Hanekom, S. Post-tuberculosis health-related quality of life, lung function and exercise capacity in a cured pulmonary tuberculosis population in the Breede Valley District, South Africa. S. Afr. J. Physiother. 2019, 75, 1319. [CrossRef]

51. Tada, A.; Matsumoto, H.; Soda, R.; Endo, S.; Kawai, H.; Kimura, G.; Yamashita, M.; Okada, C.; Takahashi, K. Effects of pulmonary rehabilitation in patients with pulmonary tuberculosis sequelae. Nihon. Kokyuki. Gakkai. Zasshi. 2002, 40, 275-281.

52. Jones, R.; Kirenga, B.J.; Katagira, W.; Singh, S.J.; Pooler, J.; Okwera, A.; Kasiita, R.; Enki, D.G.; Creanor, S.; Barton, A. A pre-post intervention study of pulmonary rehabilitation for adults with post-tuberculosis lung disease in Uganda. Int. J. Chron. Obstruct. Pulmon. Dis. 2017, 12, 3533-3539. [CrossRef]

53. Ando, M.; Mori, A.; Esaki, H.; Shiraki, T.; Uemura, H.; Okazawa, M.; Sakakibara, H. The effect of pulmonary rehabilitation in patients with post-tuberculosis lung disorder. Chest 2003, 123, 1988-1995. [CrossRef]

54. Singh, S.K.; Naaraayan, A.; Acharya, P.; Menon, B.; Bansal, V.; Jesmajian, S. Pulmonary Rehabilitation in Patients with Chronic Lung Impairment from Pulmonary Tuberculosis. Cureus 2018, 10, e3664. [CrossRef]

55. Yoshida, N.; Yoshiyama, T.; Asai, E.; Komatsu, Y.; Sugiyama, Y.; Mineta, Y. Exercise training for the improvement of exercise performance of patients with pulmonary tuberculosis sequelae. Intern. Med. 2006, 45, 399-403. [CrossRef]

56. Wilches, E.C.; Rivera, J.A.; Mosquera, R.; Loaiza, L.; Obando, L. Pulmonary rehabilitation in multi-drug resistant tuberculosis (TB MDR): A case report. Colomb. Med. 2009, 40, 436-441.

57. Betancourt-Peña, J.; Muñoz-Erazo, B.E.; Hurtado-Gutiérrez, H. Efecto de la rehabilitación pulmonar en la calidad de vida y la capacidad funcional en pacientes con secuelas de tuberculosis [Effect of pulmonary rehabilitation in quality of life and functional capacity in patients with tuberculosis sequela]. Nova 2015, 13, 47-54. [CrossRef]

58. Rivera Motta, J.A.; Wilches, E.C.; Mosquera, R.P. Pulmonary rehabilitation on aerobic capacity and health-related quality of life in patients with sequelae of pulmonary TB. Am. J. Respir. Crit. Care. Med. 2016, 193, A2321. [CrossRef]

59. Visca, D.; Centis, R.; D’Ambrosio, L.; Muñoz-Torrico, M.; Chakaya, J.M.; Tiberi, S.; Spanevello, A.; Sotgiu, G.; Migliori, G.B. Post-TB treatment pulmonary rehabilitation: Do we need more? Int. J. Tuberc. Lung. Dis. 2020, in press.

(C) 2020 by the authors. Licensee MDPI, Basel, Switzerland. This article is an open access article distributed under the terms and conditions of the Creative Commons Attribution (CC BY) license (http://creativecommons.org/licenses/by/4.0/). 